\title{
Digestion of Food Ingredients and Food Using an In Vitro Model Integrating Intestinal Mucosal Enzymes
}

\author{
Vicenta Garcia-Campayo ${ }^{1 *}$, Sonia Han1, \\ Ronny Vercauteren ${ }^{2}$, Anne Franck ${ }^{2}$ \\ ${ }^{1}$ Cargill Incorporated, Minneapolis, US \\ ${ }^{2}$ Cargill R \& D Centre Europe, Vilvoorde, Belgium \\ Email: ^Vicenta_Garcia-Campayo@cargill.com
}

How to cite this paper: Garcia-Campayo, V., Han, S., Vercauteren, R. and Franck, A. (2018) Digestion of Food Ingredients and Food Using an In Vitro Model Integrating Intestinal Mucosal Enzymes. Food and Nutrition Sciences, 9, 711-734.

https://doi.org/10.4236/fns.2018.96055

Received: May 18, 2018

Accepted: June 24, 2018

Published: June 27, 2018

Copyright (c) 2018 by authors and Scientific Research Publishing Inc. This work is licensed under the Creative Commons Attribution International License (CC BY 4.0).

http://creativecommons.org/licenses/by/4.0/

\begin{abstract}
This study focuses on the development of an in vitro digestion model simulating oral, gastric and small intestinal fluids, applicable to the digestion of all three macronutrients, carbohydrates, proteins and lipids. To that aim, the effect of integrating intestinal mucosal enzymes in the small intestinal phase of the digestion reaction was investigated, together with that of other parameters including pepsin and pancreatin concentration, and $\mathrm{pH}$ of the small intestinal phase. Individual carbohydrate and protein ingredients for which digestive properties in vivo are generally understood (i.e. common corn starch, whey protein isolate) were used as reference substrates to validate the model and, at the end of development, the model was applied to evaluate the digestion of a reference lipid ingredient (i.e. olive oil) and of all three macronutrients present in a whole food system. Carbohydrate, protein and lipid hydrolysis was monitored, respectively, by quantitation of glucose, free amino groups and free fatty acids released at different times of digestion. The results demonstrate that including intestinal mucosal enzymes in the intestinal phase of digestion in vitro allows efficient digestion of starch and other carbohydrates into final product glucose and it also influences protein hydrolysis. Digestion profiles consistent with published in vitro and in vivo data support the validity of the developed method as an advanced tool for screening digestion of all three macronutrients whether presented alone or in a whole food system, all in a single digestion reaction.
\end{abstract}

\section{Keywords}

In Vitro Model, Carbohydrate, Protein, Lipid, Digestion, Intestinal 


\section{Introduction}

Development of new food ingredients and food systems is an essential aspect of innovation in the food industry and, as an integral part of the development process, a profound chemical and rheological characterization of the new food ingredient or system is required. In addition, understanding of the digestive properties also becomes critical to the development of those new ingredients and food. Further, there is an increasing interest in the design of food structures to manipulate rate of digestion, as an approach to impact satiety and/or control location of nutrient delivery along the gastrointestinal tract [1]. A number of research articles have now demonstrated that matrix, structure, ingredient interactions and processing of foods can have a critical impact on digestion [1] [2] [3]. In vivo digestion screening tests using animal or human subjects is economically hindered, time consuming and, in the case of ingredients under development, unsafe. An alternative to in vivo digestion are in vitro digestion models which, while not without limitations, are widely accepted tools in the fields of food/feed science and nutrition to screen digestion properties prior to in vivo studies [4].

Digestion is a highly complex physiological process which includes multiple phases (mouth, stomach, small and large intestine), each of them characterized by specific solutions of unique composition (enzymes, organic and inorganic components), distinct $\mathrm{pH}$ and physicochemical/mechanical processes. That level of complexity is very difficult to completely reproduce in vitro and models are normally adapted to integrate the aspects of digestion deemed to be most relevant for a specific scientific question. Without doubt, dynamic models, capable of adjusting conditions throughout the digestion test [5] [6] [7] [8], have the ability to mimic a larger set of parameters than static models. Still, static models have an economical and large throughput advantage.

Historically, a number of static in vitro digestion models varying within a wide range of conditions have been developed [9] [10], often focused on a particular application and dedicated to studying one single type of macronutrient. For example, starch digestibility in vitro is typically evaluated by the technique of Englyst [11] which simulates gastric and small intestinal digestion, the later including porcine pancreatic $\alpha$-amylase and fungal amyloglucosidase as digestive enzymes. This technique evaluates starch digestibility by determining, through glucose analysis, three fractions: a rapidly digested $(20 \mathrm{~min})$, a slowly digested (20 - $120 \mathrm{~min}$ ) and a resistant to digestion (not digested within $120 \mathrm{~min}$ ) fractions. The in vitro analysis of lipid digestion, on the other hand, is often performed using a $\mathrm{pH}$ stat method, including a small intestinal digestion with pancreatic enzymes and for which the amount of neutralizing alkali is widely accepted to be equivalent to the fatty acids produced [12] [13]. Also a pH stat method is commonly accepted to evaluate in vitro digestion of proteins [14]. Inherent to the dissimilarities among these traditional methods is the inability to simultaneously evaluate the digestion in vitro all three macronutrients: carbohydrates, proteins and lipids. 
Advancements in this respect are seen in studies by [15] reporting the development of an in vitro digestion model that can be used to evaluate the decomposition of both proteins and lipids in milk, and also by [16] proposing a standard protocol for in vitro digestion of macronutrients and demonstrating predicted digestibility of starch in mouth, of protein in stomach and of lipid in the small intestine. More recently, a static in vitro digestion model [17] proposes harmonized conditions of digestion based on most recent knowledge from human determinations. While these newer models more precisely simulate many of the physiological conditions, there is recognition of the lack of a final step of small intestinal digestion [15] [17], during which disaccharidases and aminopeptidase enzymes of the brush border membrane (BBM) of the enterocytes (i.e. intestinal mucosal enzymes) work to complete carbohydrate and protein digestion [18]. This final step is key to providing nutrients readily for absorption across the epithelial cells. Particularly for proteins, publications [19] [20] provide evidence of the impact of BBM's enzymes on in vitro digestibility of dietary milk proteins. To our knowledge, no evidence exists on the utilization of intestinal mucosal enzymes as an integral part of a modern static in vitro model of digestion of carbohydrates and whole food systems.

The aim of this study was to develop a static in vitro digestion model that integrates conditions for simultaneously simulating carbohydrate, protein and lipid hydrolysis of foods as a tool to screen rate and extent of digestion of macronutrients as individual ingredients and in a final food product. To that effect, integrating intestinal mucosal enzyme extracts was of essence and we focused on evaluating and optimizing amount of intestinal mucosal enzyme extract needed to be incorporated into the digestion reactions that would result in physiologically relevant digestion, primarily for carbohydrates, in addition to evaluating their impact on both carbohydrate and protein hydrolysis, upon modifying other conditions of digestion, namely pepsin, pancreatin concentrations, and $\mathrm{pH}$ of small intestinal solution. Selected conditions were applied to digestion of olive oil and to a whole food system. Validation of the method was performed by testing selected reference substrates of known/expected digestibility properties and outcomes based on published human, animal and/or other in vitro data.

\section{Materials and Methods}

\subsection{Chemicals and Reagents}

$\mathrm{CaCl}_{2} \cdot 2 \mathrm{H}_{2} \mathrm{O}$ and $\mathrm{HCl}$ from EMD Chemicals; $\mathrm{KSCN}$ and Urea from JT Baker; $\mathrm{KCl}, \mathrm{MgCl}_{2}$ (hexahydrate), $\mathrm{Na}_{2} \mathrm{SO}_{4}, \mathrm{NaCl}, \mathrm{NaH}_{2} \mathrm{PO}_{4}$ (monohydrate), $\mathrm{NaHCO}_{3}$, $\mathrm{KH}_{2} \mathrm{PO}_{4}, \mathrm{NH}_{4} \mathrm{Cl}, \mathrm{NaOH}$ from BDH; bile (B-8381), Gastric Lipase (L8525, from Candida rugosa, $1 \mathrm{MU} / \mathrm{mg}$ protein), Pancreatic lipase (L3126), mucin (M1778), pancreatin (M1778), pepsin from porcine gastric mucosa (P7000), human salivary $\alpha$-amylase (A-0521, $2.5 \mathrm{kU}$ ), Rat Intestinal acetone Powder (RIP) (I 1630), Palatinose (P2007), TCA (T6399), Thimerosal (T5125), Betulin (B9757) from Sigma; Guar gum from Spectrum; Uric acid from Alfa Aesar; $\mathrm{MgSO}_{4} \cdot 7 \mathrm{H}_{2} \mathrm{O}$ from 
Mallinckrodt; Pyridin (P/N 25104) and BSTFA (P/N 38834) from Pierce Biotechnology; TLC Reference Standard (Olein mixture 18-6A) from Nu-Check Prep., Inc; Common Corn Starch (Cargill 3420), Whey Protein Isolate (BiPro, Davisco Foods); Extra Virgin Olive Oil (Bella).

\subsection{Description of the Model}

The in vitro model developed to digest ingredients and foods simulates the mouth, stomach, and small intestine fluids and was adapted from [21]. The digestive solution compositions they reported for a fed state were initially followed except that glucose, glucuronic acid, glucosamine hydrochloride and bovine serum albumin were not included in our model. In addition, Candida rugosa Lipase (CrL) and RIP-enzyme extract were introduced into the gastric and duodenal solutions, respectively. Thus, the initial composition of the digestive solutions simulating each of the digestive compartments was as follows. Saliva cocktail: $12 \mathrm{mM} \mathrm{KCl}, 2.1 \mathrm{mM} \mathrm{KSCN}, 5.1 \mathrm{mM} \mathrm{NaCl}, 7.4 \mathrm{mM} \mathrm{NaH}_{2} \mathrm{PO}_{4}, 20.2 \mathrm{mM}$ $\mathrm{NaHCO}_{3}, 4 \mathrm{mM} \mathrm{Na}_{2} \mathrm{SO}_{4}, 3.36 \mathrm{mM}$ urea, $15 \mathrm{mg} / \mathrm{L}$ uric acid, $25 \mathrm{mg} / \mathrm{L}$ mucin, 15 mg human $\alpha$-amylase $(2.5 \mathrm{kU}) / \mathrm{L} ; \mathrm{pH}$ was adjusted to 6.8 . Gastric cocktail: 11 $\mathrm{mM} \mathrm{KCl}, 47.1 \mathrm{mM} \mathrm{NaCl}, 2.2 \mathrm{mM} \mathrm{NaH} \mathrm{PO}_{4}, 1.4 \mathrm{mM}$ urea, $3.6 \mathrm{mM} \mathrm{CaCl}$, 78.7 $\mathrm{mM} \mathrm{HCl}, 5.5 \mathrm{mM} \mathrm{NH}_{4} \mathrm{Cl}, 0.2 \mathrm{~g} / \mathrm{L}$ guar gum, $3 \mathrm{~g} / \mathrm{L}$ mucin, $2.5 \mathrm{~g}$ pepsin $(1170$ $\mathrm{kU}) / \mathrm{L}, 15 \mathrm{mg}$ Candida rugosa Lipase $(\mathrm{CrL})(600 \mathrm{kU}) / \mathrm{L} ; \mathrm{pH}$ was adjusted to $1.7 \pm$ 0.2. Duodenal cocktail: $7.6 \mathrm{mM} \mathrm{KCl}, 120 \mathrm{mM} \mathrm{NaCl}, 0.5 \mathrm{mM} \mathrm{KH}_{2} \mathrm{PO}_{4}, 41.6 \mathrm{mM}$ $\mathrm{NaHCO}_{3}, 1.7 \mathrm{mM}$ urea, $2.2 \mathrm{mM} \mathrm{HCl}, 0.5 \mathrm{mM} \mathrm{MgCl}_{2}, 1.8 \mathrm{mM} \mathrm{CaCl}_{2}, 9$ g pancreatin $(31.5$ Trypsin $\mathrm{kU}) / \mathrm{L}, 1.5 \mathrm{~g}$ pancreatic lipase $(150 \mathrm{kU}) / \mathrm{L}$, dialyzed and lyophilized RIP-enzyme extract (8.5 - $140 \mathrm{IU}) / \mathrm{L}$ (equivalent to about 3 - $57 \mathrm{~g} / \mathrm{L}$ inclusion dose); $\mathrm{pH}$ was adjusted to $8 \pm 0.2$. Bile cocktail: $5 \mathrm{mM} \mathrm{KCl}, 90 \mathrm{mM}$ $\mathrm{NaCl}, 69 \mathrm{mM} \mathrm{NaHCO}_{3}, 4.2 \mathrm{mM}$ urea, $1.8 \mathrm{mM} \mathrm{HCl}, 2 \mathrm{mM} \mathrm{CaCl}_{2}, 30 \mathrm{~g}$ bile/L; $\mathrm{pH}$ was adjusted to $8.2 \pm 0.2$. Mixed inorganic reagents were prepared as stock solutions and kept at $4{ }^{\circ} \mathrm{C}$. Organic reagents and enzymes were added freshly to adequate volume aliquots of the stock solutions, prior to each experiment. Working $\mathrm{pH}$ in final duodenal-bile mix was $7.2 \pm 0.2$.

At the end of development, digestive solutions differed from initial composition as follows. Gastric cocktail: inclusion of 11 times lower concentration of pepsin $(0.225 \mathrm{~g}(105 \mathrm{kU}) / \mathrm{L})$. Duodenal cocktail: pancreatin concentration was reduced to $1 \mathrm{~g}$ (3.5 Trypsin $\mathrm{kU}$ )/L, $34 \mathrm{IU} / \mathrm{L}$ (about $14 \mathrm{~g}$ ) RIP-enzyme extract intestinal mucosal enzyme extract, $\mathrm{pH}$ adjusted to $6.5 \pm 0.2$. Bile cocktail: $\mathrm{pH}$ adjusted to $6.7 \pm 0.2$. Final $\mathrm{pH}$ in gastric phase of digestion and small intestinal mix was $3.5 \pm 0.2$ and $6.3 \pm 0.2$, respectively.

Per reaction, 20 - $200 \mathrm{mg}$ of reference materials or test ingredients (carbohydrate, protein, or lipid) are weighted into $15 \mathrm{ml}$ conical test tubes. Substrate inclusion is standardized per nutrient of interest, thus maintaining constant ratio substrate/enzyme which, depending on the nutrient concentration, can result in variable inclusion weights. Digestion starts by mixing reference substrate or test ingredient with $1 \mathrm{ml}$ of pre-warmed saliva cocktail (5 $\mathrm{U} \alpha$-amylase) in a $15 \mathrm{ml}$ 
conical test tube followed, after $5 \mathrm{~min}$, by addition of $2 \mathrm{ml}$ pre-warmed gastric cocktail (211 U pepsin, $1200 \mathrm{U}$ CrL). Working gastric $\mathrm{pH}$ is $3.5 \pm 0.2$, representative of half emptying time in vivo [22]. After $2 \mathrm{~h}$ incubation at $37^{\circ} \mathrm{C}$ with constant head-over-heels rotation, $0.3 \mathrm{ml}$ of pre-warmed $0.2 \mathrm{M}$ sodium phosphate buffer $\mathrm{pH} 6.5$ are added to raise the $\mathrm{pH}$ of the saliva-gastric solution, followed by addition of $3 \mathrm{ml}$ of a mixture of pre-warmed duodenal (7 $\mathrm{U}$ trypsin from pancreatin, $300 \mathrm{U}$ pancreatic lipase, $70 \mathrm{mIU}$ RIP-enzyme extract) and bile solutions (ratio 2:1) thus initiating the small intestinal phase of digestion. Thimerosal (19 $\mathrm{mM}$ solution) was added to final concentration of $10 \mathrm{ml} / \mathrm{L}$ to prevent bacterial growth. Working $\mathrm{pH}$ for small intestinal digestion was $6.3 \pm 0.2$, representative $\mathrm{pH}$ of the unstirred water layer that bathes the brush border [18]. Mixtures were incubated at $37^{\circ} \mathrm{C}$ under constant head-over-heels rotation. Samples $(0.33 \mathrm{ml})$ were taken recurrently at different time points during gastric $(0,2 \mathrm{~h})$ and small intestine $(0.5,1,2,3,4 \mathrm{~h})$ phases of digestion. Gastric samples were neutralized with $5 \mathrm{M} \mathrm{NaOH}$. All samples were centrifuged at 13,000 rpm and $4^{\circ} \mathrm{C}$ for $3 \mathrm{~min}$ and rapidly frozen at $-20^{\circ} \mathrm{C}$. This recurring sampling method was standard for carbohydrate and protein testing but was modified to a so called "one tube per sample and per time" method when testing lipid ingredient, thus eliminating errors inherent when aliquoting from heterogeneous liquid/oil phase digestive solutions.

Each substrate, digested in triplicate, and duplicate blanks containing all the solutions but no substrate were run under the same incubation and mixing conditions. Digestion of carbohydrates, proteins or lipids was monitored, respectively, by determining glucose, free amino groups or free fatty acids released into the digestive solutions, by the methods indicated below.

\subsection{Preparation of Crude Intestinal Mucosal Enzyme Extract from Rat Intestinal Acetone Powder}

Rat Intestinal acetone Powder (RIP) was used as a source of small intestinal disaccharidases (i.e. maltase-glucoamylase, sucrase-isomaltase) [23] [24] and amino peptidases [25]. RIP (10 g) was suspended in $200 \mathrm{ml}$ of cold $0.1 \mathrm{M}$ Phosphate buffer ( $\mathrm{pH}$ 6.0) and stirred on a magnetic stirrer for $3 \mathrm{~h}$ at $4^{\circ} \mathrm{C}$, followed by centrifugation at $10,000 \mathrm{rpm}$ for $10 \mathrm{~min}$ at $4^{\circ} \mathrm{C}$. The supernatant was further filtered on pre-folded filter paper \#588 (Whatman Schleicher \& Schuell) and dialyzed against $0.1 \mathrm{M}$ Phosphate buffer ( $\mathrm{pH} 6.0$ ) for $24 \mathrm{~h}$ at $4^{\circ} \mathrm{C}$ during which time buffer was replaced once. Dialyzed solution was lyophilized and stored frozen at $-20^{\circ} \mathrm{C}$ for up to 3 months. The activity of the crude intestinal mucosal enzyme extract was standardized based on the sucrase-isomaltase activity which was determined using isomaltulose (palatinose) as substrate. Briefly, $0.06 \mathrm{~g}$ of crude enzyme extract, $5.4 \mathrm{ml}$ of $0.1 \mathrm{M}$ Phosphate buffer ( $\mathrm{pH} 6.0$ ) and $0.6 \mathrm{ml}$ of $29 \mu \mathrm{M}$ isomaltulose substrate were incubated at $37^{\circ} \mathrm{C}$ in a shaking water bath for $30 \mathrm{~min}$. The amount of liberated glucose was determined using the glucose oxidase-peroxidase assay, as described below. One unit of activity is defined as the amount of enzyme that released $1 \mu \mathrm{mol}$ of glucose per minute under the conditions described. 


\subsection{Determination of Glucose Content}

The glucose content of the samples was determined by an enzymatic (GOPO)colorimetric reaction using Stanbio glucose Liquicolor reagent (Stanbio Laboratories). Briefly, $10 \mu \mathrm{l}$ of sample or glucose standard $(0-4 \mathrm{mg} / \mathrm{mL})$ were mixed with $1 \mathrm{ml}$ glucose reagent and incubated at room temperature for $30 \mathrm{~min}$. Absorbance was read at $500 \mathrm{~nm}$ (Synergy HT, Biotek). Results were expressed as percentage of total starch equivalent conversion to glucose.

\subsection{Determination of Free Amino Groups}

Free amino groups content was determined by TNBS (2,4,6-trinitrobenzene sulfonic acid; Picrylsulfonic Acid) method after protein precipitation with trichloroacetic acid (TCA) [26]. Briefly, 55\% TCA solution was added to digesta samples at $1 / 10(\mathrm{v} / \mathrm{v})$ ratio and incubated at $4^{\circ} \mathrm{C}$ for at least one hour. Samples were centrifuged at $13,000 \mathrm{rpm}$ and $4^{\circ} \mathrm{C}$ for $5 \mathrm{~min}$ and aliquots of clean supernatants were diluted $1 / 10$ with $2.5 \%$ borate buffer $\mathrm{pH} 9.5$. For reactions, $50 \mu \mathrm{l}$ of diluted samples or $50 \mu \mathrm{l}$ of Leucine standard solutions $(0-6 \mathrm{mM})$ were mixed with $1 \mathrm{ml}$ of $2.5 \%$ borate reagent and $20 \mu \mathrm{l}$ of $0.5 \%$ TNBS, and incubated at room temperature for $30 \mathrm{~min}$. Reactions were stopped by adding $0.5 \mathrm{ml}$ of $1 \mathrm{M} \mathrm{NaH}_{2} \mathrm{PO}_{4}$ and absorbance was read at $420 \mathrm{~nm}$. Degree of hydrolysis was expressed as \% of free amino groups released from total, where total is the total number of amino groups per protein equivalent, calculated from the amount of protein included in the digestion reaction divided by the average molecular weight of amino acids (125 $\mathrm{g} /$ mole for most proteins) making a total number of peptide bonds per $\mathrm{kg}$ of protein of about $8 \mathrm{~g}$ equivalents [27] [28]. At each time point, the free amino group content measured in incubated blanks containing digestive juices and enzymes but no substrate, was deducted from that of test samples.

\subsection{Determination of Free Fatty Acids (FFA)}

FFAs were analyzed by Gas Chromatography (GC, Agilent 6890 Plus) using Flame Ionization Detection (FID). Digestion samples were acidified with $100 \mu \mathrm{l}$ of concentrated $\mathrm{HCl}$ and total lipids extracted with $6 \mathrm{ml}$ of Diethyl methane. The tubes were vigorously shaken and centrifuged at $1500 \mathrm{rpm}$ for $5 \mathrm{~min}$ at room temperature. A glass pipette was used to recover $5 \mathrm{ml}$ of the upper phase and transfer into clean tubes. Solvent was evaporated to dryness under Nitrogen flow. Lipids were dissolved in $5 \mathrm{ml}$ of toluene containing internal standard Betulin $(0.8 \mathrm{mg} / \mathrm{ml})$ and a $90 \mu \mathrm{l}$ aliquot of each sample was transferred to amber GC vials and mixed with $0.5 \mathrm{ml}$ of Pyridine and $1 \mathrm{ml}$ of BSTFA. An external standard, reference mixture containing $25 \%$ of each oleic acid, monoolein, diolein and triolein, was also dissolved in $5 \mathrm{ml}$ of toluene containing the internal standard and treated as indicated for the samples. Separation was performed on a DBTM-5HT capillary column $(15 \mathrm{~m} \times 0.25 \mathrm{~mm}$ i.d. $\times 0.1 \mu \mathrm{m} \mathrm{df})$ using Hydrogen as gas carrier at a flow rate of $40 \mathrm{ml} / \mathrm{min}$ and inlet pressure of $6.7 \mathrm{psi}$ (at $110^{\circ} \mathrm{C}$ ). The temperature was programmed as follows: $110^{\circ} \mathrm{C}$ initial, hold 0.2 
min, $30^{\circ} \mathrm{C} / \mathrm{min}$ to $140^{\circ} \mathrm{C}, 10^{\circ} \mathrm{C} / \mathrm{min}$ to $340^{\circ} \mathrm{C}$, hold $10 \mathrm{~min}$, with $1 \mathrm{~min}$ equilibration time. Run time was $33 \mathrm{~min}$ and injection volume $1 \mu \mathrm{l}$. The FID temperature was $370^{\circ} \mathrm{C}$. Empower ${ }^{\mathrm{Tm}}$ software was used to generate calibration curves from inputting weights (external and internal standards). Results were expressed as FFA released on a w/w percentage.

\subsection{Determination of Trypsin Activity}

Trypsin activity of pancreatin was measured as indicated in [17], with modifications. Briefly, three concentrations of pancreatin $(0.5,0.25,0.1 \mathrm{mg} / \mathrm{ml})$ were prepared in double distilled cold water and stirred for $10 \mathrm{~min}$. For each assay, 2.6 $\mathrm{ml}$ of $46 \mathrm{mM}$ sodium phosphate buffer containing $11.5 \mathrm{mM} \mathrm{CaCl}_{2}(\mathrm{pH} 8.1), 0.3$ $\mathrm{ml}$ of a $10 \mathrm{mM}$ TAME (p-Toluene-Sulfonyl-L-arginine methyl ester) solution in double distilled water were pipetted into quartz cuvettes, mixed by inversion and incubated at room temperature in a spectrophotometer for $5 \mathrm{~min}$. Then, for each concentration tested, $0.1 \mathrm{ml}$ of pancreatin solution was added and absorbance at $247 \mathrm{~nm}$ recorded every minute for at least $10 \mathrm{~min}$. The slope $(\Delta \mathrm{A} 247)$ was determined from the initial linear portion of the curve. For blank assays, no enzyme was added and absorbance was also recorded every minute for at least 10 min and the slope was then determined. Calculation of enzyme activity was performed using the following formula:

$$
\text { Units } / \mathrm{mg}=[(\Delta \mathrm{A} 247 \text { test }-\Delta \mathrm{A} 247 \text { blank }) * 1000 * 3] /(540 * \mathrm{X})
$$

where: $\triangle \mathrm{A} 247$ is the slope (unit absorbance/minute) determined from the initial linear portion of the curve, 3 is volume of reaction mix $(\mathrm{ml}), 540$ is the molar extinction coefficient of TAME at $247 \mathrm{~nm}$, and X is the quantity $(\mathrm{mg})$ of pancreatin in the final reaction mixture.

\subsection{Electrophoresis}

SDS-PAGE was performed using a Mini-Protean ${ }^{\circledR}$ Tetra Cell (Bio-Rad), according to manufacturer's instructions. Digestion samples and blanks (containing digestive solutions with enzymes and bile but no substrate) were reconstituted taking into account dilution during the gastric and small intestinal phases and solubilized in 2x Laemmli sample buffer (\#161-0737, Bio-Rad). After addition of ß-mercaptoethanol (2\%), samples were boiled for $5 \mathrm{~min}$. Equal volume of samples were loaded onto Mini-Protean ${ }^{\mathbb{B}}$ TGX gels (\#456-9034, Bio-Rad). Bio-Rad Precision Plus Protein Western C standard (\#161-0376) was also run in the gels. Proteins were stained with Coomassie Safe (Bio-Rad Laboratories) and destained in water. Gels were imaged with a Li-Cor Odyssey infrared imager.

\section{Results}

\subsection{Impact of Intestinal Mucosal Enzyme Extract (RIP-Enzyme Extract) Concentration on Starch Digestion}

Concentration of intestinal mucosal enzyme extracts was optimized primarily 
for starch digestion, macronutrient for which disaccharidases present in these extracts are required to achieve complete conversion to final product glucose. Common native corn starch, a material for which digestibility properties are commonly described in the literature, was selected as initial test substrate. In vitro digestion was evaluated under the initial conditions described in Materials and Methods with varying amounts of RIP-enzyme extract, ranging from 0 - 270 mIU of sucrase-isomaltase activity per reaction, added to the small intestinal solution. As shown in Figure 1, starch hydrolysis, as measured by final product glucose release, was not observed in the gastric phase of digestion while, in the small intestinal phase, starch digestion directly increased with the amount of RIP-enzyme extract. Thus, after $4 \mathrm{~h}$ of small intestinal phase less than $20 \%$ of starch $(14.2 \% \pm 0.5 \%)$ was converted to glucose in the absence of RIP-enzyme extract and around $35 \%$ digestion $(34.7 \% \pm 1.8 \%)$ was observed in the presence of the lowest amount of RIP-enzyme extract tested (17 mIU). Extent of starch digestion was enhanced up to $53.7 \% \pm 1.0 \%$ in the presence of $34 \mathrm{mIU}$ RIP-enzyme extract and close to $80 \%$ glucose release $(77.7 \% \pm 2.1 \%)$ was measured at the end of the intestinal phase of digestion in the presence of $70 \mathrm{mIU}$ RIP-enzyme extract. Higher than $90 \%$ glucose was released at the end of small intestinal phase when including 140 or 270 mIU RIP-enzyme extract.

\subsection{Effect of Varying Gastric and Duodenal Conditions in the Presence of a Given Concentration of Intestinal Mucosal Enzyme Extract on Starch Digestion}

While maximum starch digestibility was demonstrated for the two highest

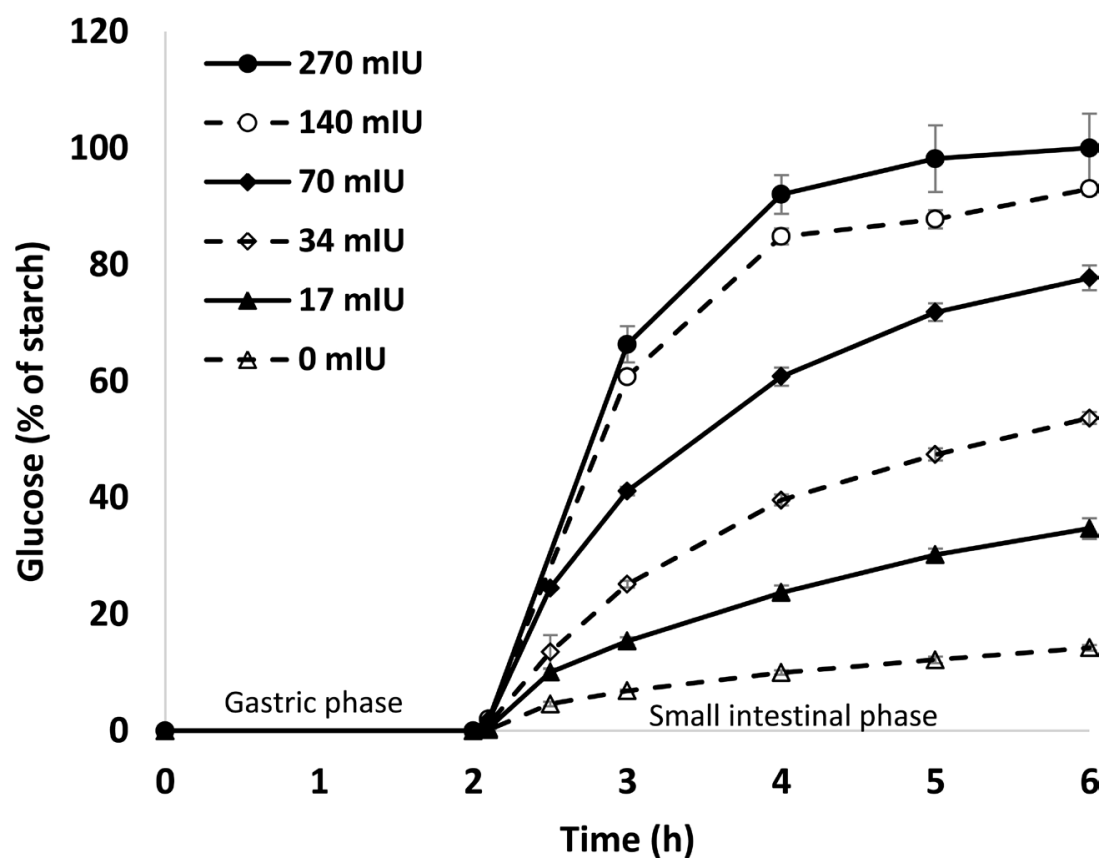

Figure 1. In vitro digestion of corn starch under initial method conditions, in the absence and in the presence of different inclusion doses of intestinal mucosal extracts (RIP-enzyme extract $)(n=3)$. 
concentrations of RIP-enzyme extract tested (140 and 270 mIU IM activity), an amount of RIP-enzyme extract resulting in less than maximum hydrolysis of starch $(70 \mathrm{mIU})$ was selected to evaluate the effect of modifying other digestion conditions in the small intestinal phase. We targeted $\mathrm{pH}$ and pancreatin inclusion. It is known that mucosal disaccharidases exhibit an optimum $\mathrm{pH}$ of 6.0 6.5 [24] [29] and we hypothesized that lowering the small intestinal $\mathrm{pH}$ and/or reducing potential endogenous proteolytic activity by lowering pancreatin inclusion could result in higher disaccharidase activity and digestibility of starch. Thus, pancreatin was tested at 7 Trypsin U per digestion reaction (9 times lower concentration than original conditions), and $\mathrm{pH}$ was reduced by one unit in the final small intestinal mix, from $\mathrm{pH} 7.2 \pm 0.2$ to $\mathrm{pH} 6.3 \pm 0.2$. The concentration of pepsin in the gastric phase was also tested at a $11 \mathrm{x}$ lower concentration $(211 \mathrm{U}$ per digestion reaction) and this modification, while not expected to impact starch digestion, was evaluated to be consistent with protein digestion testing conditions (protein digestion section below).

As shown in Figure 2, in the presence of 70 mIU of RIP-enzyme extract, maintaining the original intestinal $\mathrm{pH}(\mathrm{pH} 7.2 \pm 0.2)$ and lowering the amount of pepsin and pancreatin did not have an impact on the glucose release from corn starch compared to higher (original) inclusion of those digestive enzymes. However, lowering the intestinal $\mathrm{pH}$ by about one unit $(\mathrm{pH} 6.3 \pm 0.2)$, resulted in faster and more extended hydrolysis of corn starch, despite the lower inclusion of pancreatin. Under these conditions (70 mIU RIP-enzyme extract, $211 \mathrm{U}$ pepsin, $7 \mathrm{U}$ trypsin activity from pancreatin, per reaction, and intestinal $\mathrm{pH} 6.3$ \pm 0.2 ), hydrolysis was comparable to that previously observed with original concentration of pepsin and pancreatin and 3 and 4 times higher amounts of RIP enzyme extract (140 and 270 mIU, respectively) (shown in Figure 1), with about $95 \%$ total glucose released after $4 \mathrm{~h}$ of small intestinal digestion. From these results, $211 \mathrm{U}$ pepsin in the gastric phase, $70 \mathrm{mIU}$ of RIP-enzyme extract (corresponding to about $15 \mathrm{~g} / \mathrm{L}$ duodenal solution), and 7 trypsin $\mathrm{U}$ from pancreatin, respectively, in the small intestinal phase, and pH $6.3 \pm 0.2$ in the final small intestinal mix, were selected as adequate conditions for digestion of corn starch and utilized for further experiments.

\subsection{Evaluation of the Effect of RIP Enzyme Extract and Varying Gastric and Duodenal Conditions on the in Vitro Digestion of Proteins}

Intestinal mucosa is not only a source of disaccharidases but also aminopeptidase enzymes. As such, the effect of the inclusion dose of RIP enzyme extract optimized for carbohydrate digestion $(70 \mathrm{mIU})$ was also evaluated on protein digestion. Whey Protein Isolate (WPI) was utilized as reference material. Consistent with the different conditions tested for carbohydrate digestion, whey protein digestion was also evaluated under high (original at start of method development) and low, factor of 11 and 9, pepsin and pancreatin concentrations, respectively, and high $(7.2 \pm 0.2)$ and low $(6.3 \pm 0.2) \mathrm{pH}$ in the small intestinal phase. 


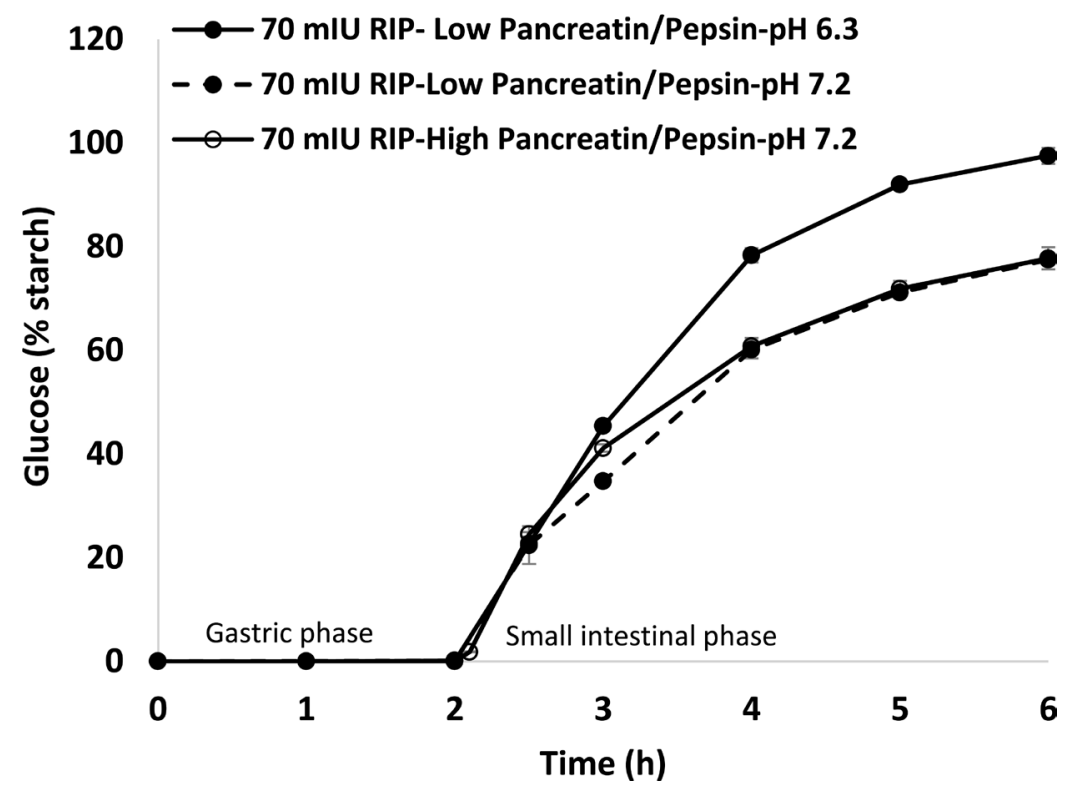

Figure 2. In vitro digestion of corn starch in the presence of intestinal mucosal extract (RIP-enzyme extract) and modified method conditions (pepsin and pancreatin inclusion and small intestinal $\mathrm{pH})(\mathrm{n}=3)$.

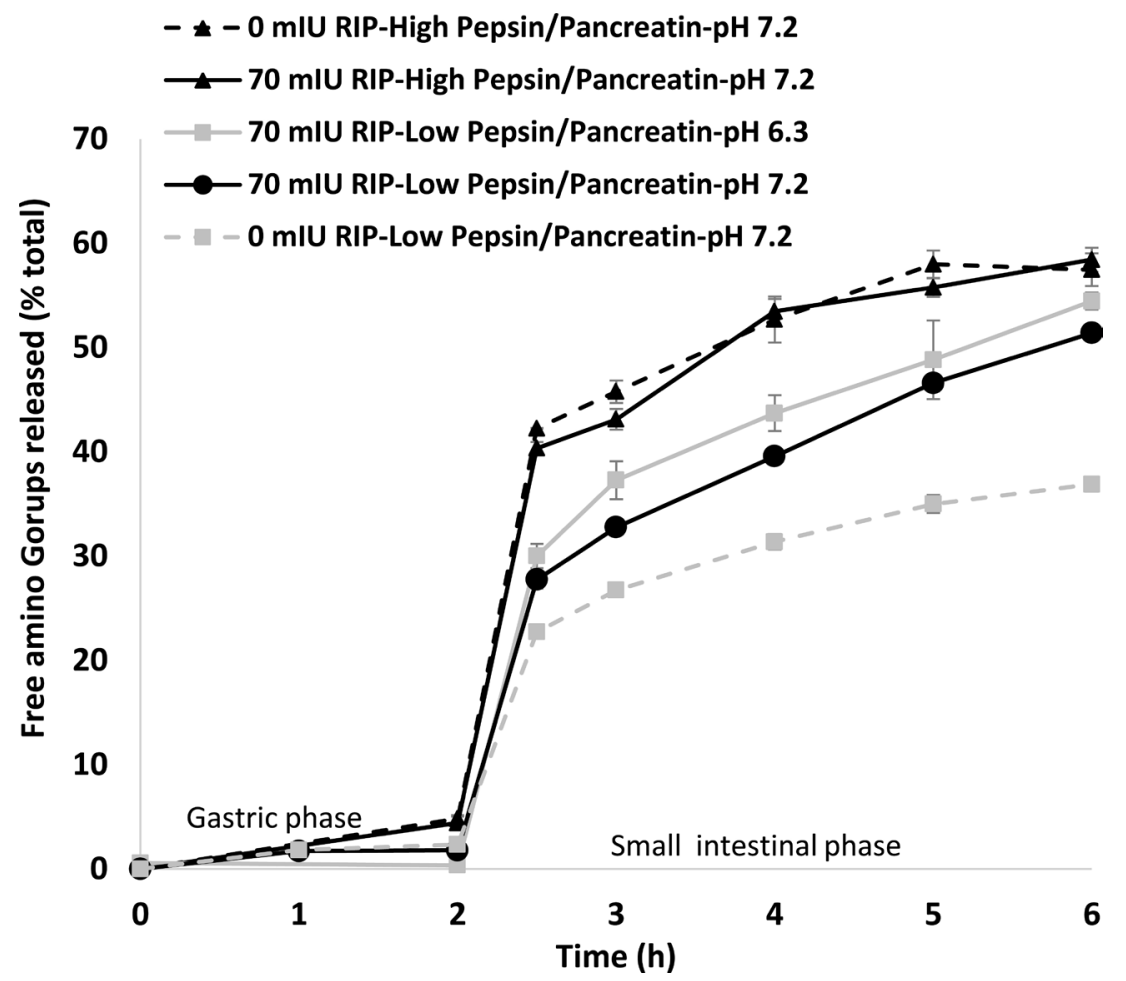

Figure 3. In vitro digestion of Whey Protein Isolate (WPI) $(\mathrm{n}=3)$ : in the presence and absence of intestinal mucosal enzymes (RIP-enzyme extract), under initial and modified method conditions.

As it can be observed in Figure 3, at the conditions tested at the start of method development (i.e. $2.3 \mathrm{kU}$ pepsin, 63 trypsin $\mathrm{U}$ from pancreatin, per digestion reaction, and high intestinal pH $7.2 \pm 0.2$ ), about $5 \%$ free amino group re- 
lease was detected at the end of $2 \mathrm{~h}$ gastric digestion. This rapidly increased up to about $40 \%$ free amino groups within 30 min of small intestinal digestion, reaching $57.5 \% \pm 1.6 \%$ at the end of $4 \mathrm{~h}$ small intestinal phase. Addition of RIP-enzyme extract did not appear to influence the in vitro digestion of whey protein isolate and similar digestion, $58.4 \% \pm 1.2 \%$ of amino groups release after $4 \mathrm{~h}$ of small intestinal digestion, was observed in the presence and in the absence of RIP-enzyme extract. In contrast, when lower concentrations of pepsin (211 U) and pancreatin (7 Trypsin U) were present, respectively $11 \times$ and $9 \times$ reduction from original inclusion dose, addition of RIP-enzyme extract positively impacted whey protein digestion. Thus, about $15 \%$ higher amino groups release was measured after $4 \mathrm{~h}$ small intestinal phase when RIP-enzyme extract was included in the digestion reaction $(51.4 \% \pm 0.5 \%)$ compared to reactions lacking RIP-enzyme extract $(36.9 \% \pm 0.7 \%)$. Under the lower digestive enzymes (pepsin and pancreatin) conditions, lowering the $\mathrm{pH}$ of the small intestinal phase from $7.2 \pm 0.2$ to about $6.3 \pm 0.2$ did not result in appreciable differences. While about $10 \%$ higher free amino group release was obtained at the early stages of the intestinal phase under the conditions tested at the start of method development $(40.4 \% \pm 0.6 \%$ vs $30.0 \% \pm 1.1 \%$ after $30 \mathrm{~min})$, the fact that the extent of digestion, $58.4 \% \pm 1.2 \%$ free amino groups, was comparable to that observed with the modified conditions selected for carbohydrate digestion (70 mIU RIP, $211 \mathrm{U}$ pepsin and $7 \mathrm{U}$ trypsin activity (from pancreatin), per digestion reaction, and intestinal $\mathrm{pH} 6.3 \pm 0.2)(54.5 \% \pm 0.8 \%)$, supports the adequacy of adopting the later conditions for protein digestion as well.

The digestion of whey protein was also monitored by SDS-PAGE as seen in Figure 4. Under the selected conditions for carbohydrate digestion, $\beta$-Lactoglobulin, the most abundant component in undigested whey protein isolate product (lane 5) was resistant to the action of pepsin (lane 6) but was rapidly digested by the enzymes present in the simulated intestinal mix (lanes 7-9). $\alpha$-lactalbumin component was partially digested after $2 \mathrm{~h}$ of gastric digestion (lane 6) and was practically undetected after $30 \mathrm{~min}$ of intestinal digestion (lane 7). In general, there was a clear shift from high molecular weight components present in the undigested material (lane 5) to lower molecular weight bands after $2 \mathrm{~h}$ of pepsin digestion (lane 6). After $4 \mathrm{~h}$ of small intestinal digestion (lane 9) SDS-PAGE profile is comparable to that of blank (lane 3 ) in which the visible bands correspond to the proteins present in the digestive solutions, this clearly demonstrating the extensive hydrolysis of whey protein components.

\subsection{Reproducibility of Digestion: RIP Enzyme Extracted from Different Batches}

To evaluate the reproducibility of digestion under the final conditions of the model, namely for corn starch and whey protein isolate, macronutrients for which intestinal mucosal enzymes are relevant, ingredients were submitted to the digestibility protocol using 3 different batches of RIP enzyme extracts. The average digestibility, standard deviation and \% Coefficient of Variation (CV) of 


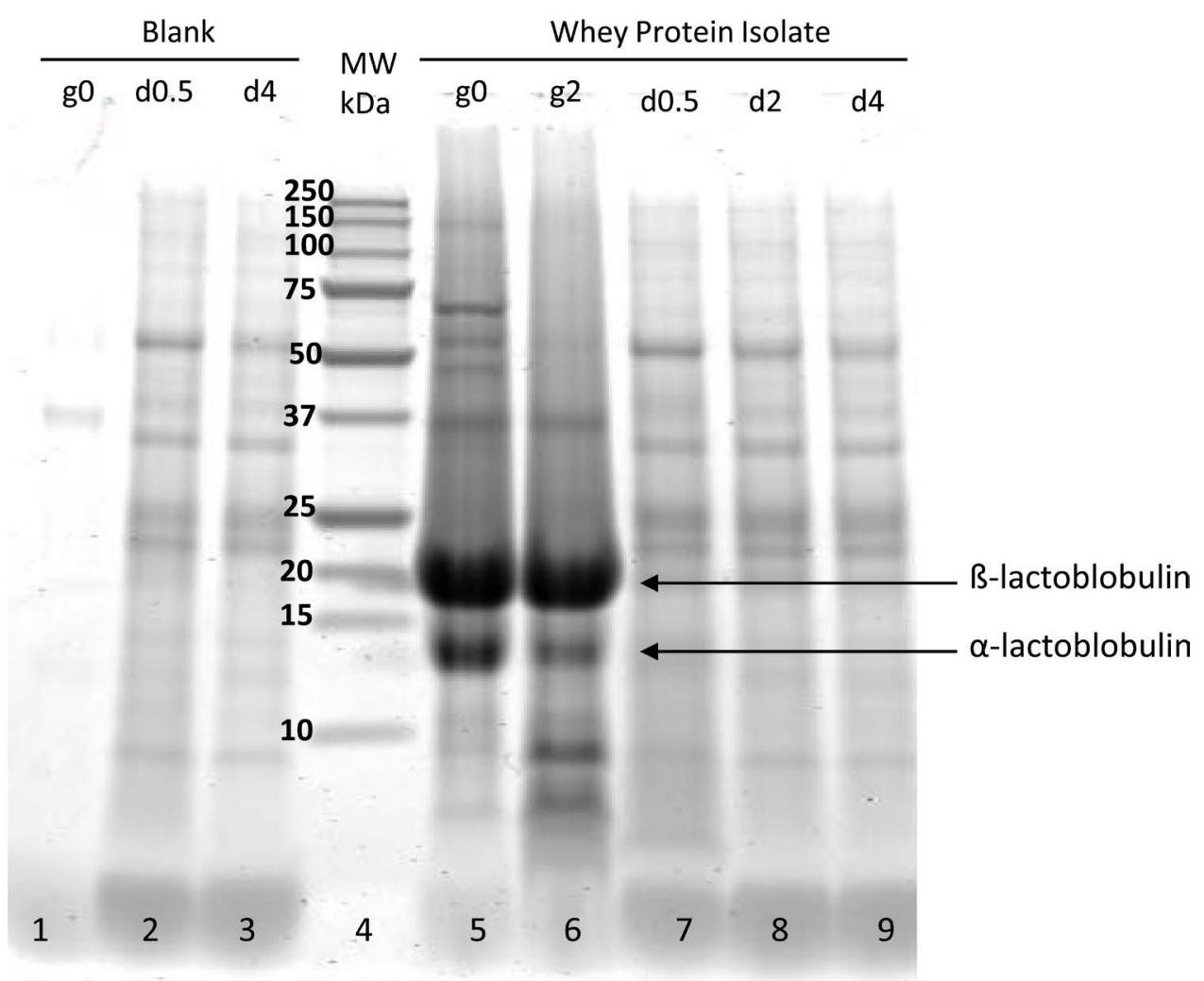

Figure 4. SDS-PAGE analysis of Whey Protein Isolate (WPI) and Blanks (digestive solutions and enzymes) at different gastric and small intestinal times of digestion in vitro. Lanes: (1) Blank at gastric time zero, (2) Blank at small intestinal time $0.5 \mathrm{~h}$, (3) Blank at small intestinal time $4 \mathrm{~h}$, (4) Protein Molecular Weight standard, (5) WPI at time zero of gastric digestion, (6) WPI after $2 \mathrm{~h}$ gastric phase, (7) WPI at $0.5 \mathrm{~h}$ into small intestinal digestion, (8) WPI at $2 \mathrm{~h}$ small intestinal digestion, (9) WPI after $4 \mathrm{~h}$ small intestinal digestion.

three independent experiments $(\mathrm{n}=3$ biological replicates of RIP enzyme extracts) where the ingredients were tested in triplicate (total $n=9$ replicates), and at different times of digestion, is shown in Table 1. \% CV of corn starch and whey protein isolate was lower than $8 \%$ at different times of digestion $(0.5,1,2$, 3 and $4 \mathrm{~h}$ small intestinal phase).

\subsection{Lipid Olive Oil Digestion}

As indicated in the Materials and Methods section, one tube per time per sample approach was used to minimize recovery losses due to the heterogeneity of the digestive solutions when testing lipids as single ingredients.

In vitro digestion of reference substrate olive oil was evaluated under the conditions selected for starch digestion and also adopted for protein digestion (70 mIU RIP-enzyme extract, $211 \mathrm{U}$ pepsin and $7 \mathrm{U}$ trypsin activity (from pancreatin), per digestion reaction, and intestinal $\mathrm{pH} 6.3 \pm 0.2$ ). Under these conditions, and in the absence of an adequate commercial mammalian gastric lipase, Candida rugosa lipase $(\mathrm{CrL})$ was included in the gastric phase and tested at $1200 \mathrm{U}$ per digestion reaction. As shown in Figure 5, 6.3\% $\pm 0.1 \% \mathrm{FFA}(\mathrm{w} / \mathrm{w})$ were released 
Table 1. Reproducibility of corn starch and whey protein isolate in vitro digestion ${ }^{\mathrm{a}}$.

\begin{tabular}{ccccccc}
\hline & \multicolumn{3}{c}{ Corn Starch } & \multicolumn{4}{c}{ Whey Protein Isolate } \\
\cline { 2 - 7 } Time (h) & $\begin{array}{c}\text { Glucose } \\
\text { (\% of starch) }\end{array}$ & SD & \% CV & $\begin{array}{c}\text { Free Amino Groups } \\
\text { (\% of total) }\end{array}$ & SD & \% CV \\
\hline 2.5 & 27.78 & 1.80 & 6.47 & 26.91 & 1.41 & 5.25 \\
3 & 48.35 & 2.67 & 5.51 & 36.01 & 2.66 & 7.38 \\
4 & 75.58 & 2.73 & 3.62 & 45.08 & 2.08 & 4.61 \\
5 & 84.79 & 3.22 & 3.80 & 48.75 & 2.98 & 6.12 \\
6 & 91.84 & 2.04 & 2.22 & 53.09 & 3.35 & 6.31 \\
\hline
\end{tabular}

${ }^{a}$ Three independent experiments performed with 3 different batches of RIP enzyme extracts and samples tested in triplicate (i.e. 9 analytical samples per time point).

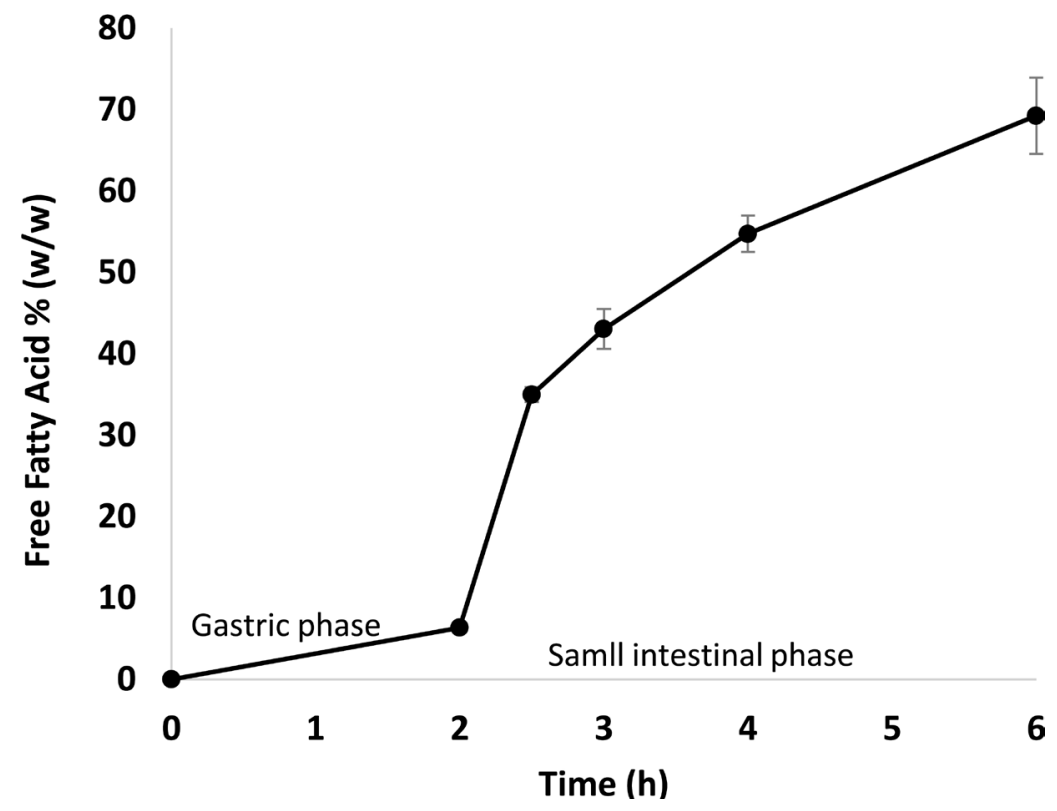

Figure 5. Total Free Fatty Acids (\% w/w) released during in vitro gastric and small intestinal digestion of olive oil $(n=3)$.

after $2 \mathrm{~h}$ of gastric digestion. A rapid increase in FFA released, $34.9 \% \pm 0.9 \%$ FFA (w/w), was observed within $30 \mathrm{~min}$ of small intestinal digestion and $69.2 \%$ $\pm 4.7 \%$ FFA $(\mathrm{w} / \mathrm{w})$ were detected at the end of $4 \mathrm{~h}$ small intestinal phase. Furthermore, about 20\% TAG and less than 5\% TAG (w/w) were measured, respectively, at $30 \mathrm{~min}$ and at the end of small intestinal digestion (data not shown).

\subsection{In Vitro Digestion of a Whole Food System}

A commercially available product, Ensure nutrition powder, was selected as an example of a complete and balanced food system from which digestibility of all 3 macronutrients could be evaluated in the developed in vitro model, all within the same digestion reaction. In order to obtain enough amount of sample to perform all the analytical tests required, the in vitro digestion was scaled up by a factor of 6 . Thus, when $1 \mathrm{ml}, 2 \mathrm{ml}$ and $3 \mathrm{ml}$ of saliva, gastric and small intestinal solutions, respectively, represent the volumes of a typical reaction for a single 
ingredient, digestion of the whole food was performed utilizing $6 \mathrm{ml}, 12 \mathrm{ml}$ and $18 \mathrm{ml}$ of the above solutions. Amount of food inclusion, based on nutrients present at the lowest concentration (protein and fat), was also scaled by a factor of 6 this resulting in $1.2 \mathrm{~g}$ of Ensure powder added to the reaction tubes. Nutrient composition of Ensure nutrition powder, based on manufacturer nutritional label, is $16 \%$ fat, $60 \%$ carbohydrate and $16 \%$ protein. Testing lipid digestibility on a whole food system did not require the "one tube per sample and per time" approach given the naturally emulsifying properties provided by the food matrix.

Digestion of all three macronutrients proceeded simultaneously and the curves of digestion are shown in Figure 6. For the carbohydrate component of the food system, $3.4 \% \pm 1.2 \%$ of free glucose was detected at time zero of digestion and this amount was still present after $2 \mathrm{~h}$ of gastric phase; $34.0 \% \pm 1.7 \%$ and $64.3 \% \pm 2.2 \%$ glucose equivalent percent of the total carbohydrate was observed during the first $30 \mathrm{~min}$ and after $4 \mathrm{~h}$ of small intestinal digestion, respectively. Regarding the protein component, $1.2 \% \pm 0.4 \%$ free amino groups were detected after $2 \mathrm{~h}$ of gastric digestion and $24.6 \% \pm 1.1 \%$ after $30 \mathrm{~min}$ of small intestinal phase. At the end of digestion, $52.3 \% \pm 2.2 \%$ free amino groups were measured. About $10 \% \mathrm{FFA}(\mathrm{w} / \mathrm{w})$ was detected after $2 \mathrm{~h}$ of gastric digestion and about $48.4 \% \pm 0.5 \%$ FFA (w/w) were measured after $0.5 \mathrm{~h}$ small intestinal digestion, reaching after $4 \mathrm{~h}, 66.8 \% \pm 1.2 \% \mathrm{FFA}(\mathrm{w} / \mathrm{w})$.

\section{Discussion}

In this study, conditions of digestion in vitro were evaluated for achieving

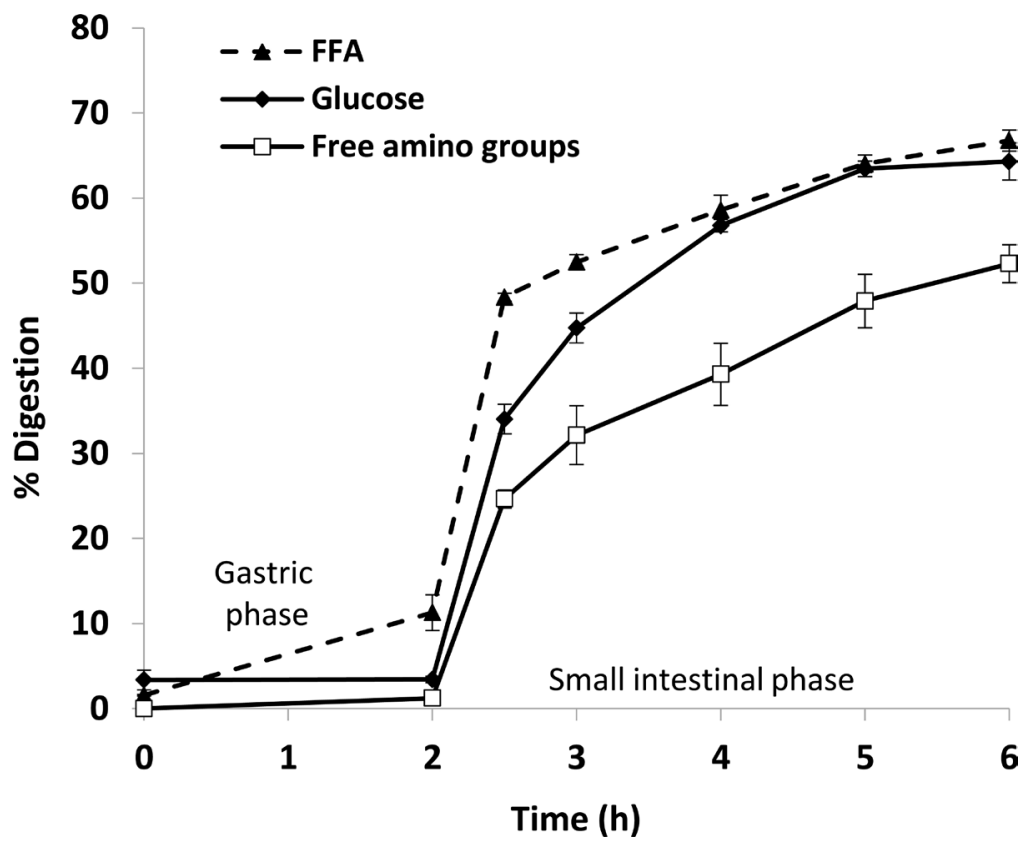

Figure 6. In vitro digestion of a whole food system Ensure Nutrition Powder $(\mathrm{n}=3)$. \% Digestion represents Glucose (\% of starch), Free Amino Groups (\% of total) and Free Fatty Acids\% (w/w), for carbohydrate, protein and lipid components, respectively. 
simultaneous hydrolysis of all three macronutrients (carbohydrate, protein and lipid) of foods, within physiological range. At this effect, intestinal mucosal enzymes were integrated in the digestion reactions, as they are a critical component for the final step of starch and protein hydrolysis which renders nutrients available for absorption across the epithelial cells [18]. Digestion of starches in humans initially relies on $\alpha$-amylase (both salivary and pancreatic) which hydrolyzes internal $\alpha$-1,4 linkages and releases maltose and $\alpha$-limit dextrins. Those become substrate for the mucosal $\alpha$-glucosidases, including maltase-glucoamylase and sucrase-isomaltase complexes, with ability to hydrolyze $\alpha-1,4, \alpha-1,6$, and $\alpha-1,3$ linkages in di- and oligo-saccharides [18] [30]. Furthermore, work with recombinant human small intestinal maltase-glucoamylase [31] has shown that this disaccharidase also has capability to hydrolyze native starch granules. These authors also evaluated the impact of fungal Amyloglucosidase (AMG), enzyme typically included in in vitro models for carbohydrate digestion such as the extensively utilized Englyst method [11], on morphology of native starches of different botanical origins and compared it to that of human recombinant maltase-glucoamylase. Interestingly, remarkable differences on the morphology of starch granules were observed by scanning electron microscopy, demonstrating different susceptibilities of raw starches from different botanical sources to the two enzymes (human and fungal), thus strengthening the significance of including mammalian intestinal mucosal enzyme extracts versus fungal Amyloglucosidase when modeling digestion in vitro. Additional evidence amplifying the physiological relevance of including mammalian intestinal mucosal enzymes in in vitro digestion models, as it relates to proteins, comes from the fact that more than 20 major peptidases have already been identified in the small intestinal brush border membrane of humans and rats [32].

The initial in vitro conditions of digestion utilized in this study were based on the model described by [21], a model that has been extensively used as reference by others [15] [33]. From there, this study focused on evaluating and optimizing the amount of intestinal mucosal enzyme extract needed to be incorporated into digestion reactions that would result in approximate to physiological digestion, in addition to evaluating its impact upon modifying other conditions of digestion, namely pepsin and pancreatin concentrations, and $\mathrm{pH}$ of small intestinal solution.

Intestinal mucosal extracts include a complex mixture of enzymes which makes quantitation of all activities difficult. Carbohydrate digestion was prioritized for testing and thus, standardization of the extract was done on the basis of disaccharidase sucrase-isomaltase (palatinase) activity. At the initial conditions tested, which did not include intestinal mucosal extracts, less than $20 \%$ of starch was converted into glucose after $4 \mathrm{~h}$ of small intestinal digestion. Upon addition of intestinal mucosal enzymes, starch digestion consistently increased with increasing intestinal mucosal extract concentration up to $140 \mathrm{mIU}$ (palatinase activity) inclusion, level at which digestibility of starch appeared to be maximized and doubling inclusion of intestinal mucosal enzyme extract did not result in 
faster or more extended digestion. Two factors were hypothesized that could have a significant impact on the in vitro digestibility of starch in the presence of intestinal mucosal enzymes: $\mathrm{pH}$ in the small intestinal phase and inclusion of pancreatin. The $\mathrm{pH}$ of the small intestinal phase of these initial in vitro experiments was $7.2 \pm 0.2$ and it is known that mucosal disaccharidases exhibit an optimum $\mathrm{pH}$ of 6.0 - 6.5 [24] [29]. Pancreatin positively contributes to starch digestion by providing pancreatic $\alpha$-amylase but a potential negative effect due to proteolytic action on intestinal mucosal enzymes could also be hypothesized. Thus, it appeared appropriate to evaluate the effect of lowering the $\mathrm{pH}$ in the final mix as well as pancreatin inclusion, utilizing a dose of small intestinal mucosal extract below that resulting in maximal hydrolysis. Results showed that, when small intestinal $\mathrm{pH}$ was maintained at $7.2 \pm 0.2$, lowering pancreatin inclusion by a factor of 9 decreased starch digestion. However, lowering the small intestinal $\mathrm{pH}$ to $6.2 \pm 0.2$ reversed this effect and, despite the lower concentration of pancreatin, starch digestion was increased to levels comparable to those observed with initial conditions including higher pancreatin levels and twice and four times higher inclusion of RIP-enzyme extract. This data, while not demonstrating whether inactivation of mucosal enzymes by proteolytic effect at high pancreatin inclusion level occurs, does demonstrate the importance of the small intestinal $\mathrm{pH}$ in the complex digestion reactions and supports a small intestinal $\mathrm{pH}$ of $6.2 \pm 2$, the inclusion of small intestinal mucosal enzyme extract at 70 $\mathrm{mIU}$, and 9 times lower inclusion of pancreatin than in the original model, as adequate conditions for further experiments. Under these conditions, common corn starch was digested at about $25 \%-30 \%$ after $30 \mathrm{~min}$ and around $80 \%$ after $2 \mathrm{~h}$ of small intestinal phase, the later representing 50\%-55\% digestion occurring from $30-120$ min. Hydrolysis reached more than $90 \%$ after $4 \mathrm{~h}$ of small intestinal digestion. These values are in good agreement with those observed for digestible starch [34], on the basis of the in vitro Englyst method, widely used for carbohydrate digestibility, showing $22.4 \%, 53.0 \%$ and $22.6 \%$ as percentages for rapidly digestible starch (RDS, $20 \mathrm{~min}$ ), slowly digestible starch (SDS, 20 - 120 $\mathrm{min}$ ) and resistant starch (RS, not digested at $120 \mathrm{~min}$ ) from common maize starch. However, when the kinetics of enzymatic hydrolysis were followed beyond the standard $2 \mathrm{~h}$ digestion time, almost $100 \%$ digestibility of native maize starch was observed, this suggesting that the $2 \mathrm{~h}$ time point of digestion of the Englyst method is too short to accurately represent the resistant starch fraction of native starches. In addition, work comparing in vitro starch digestion using a modified Englyst model with in vivo portal glucose appearance in pigs [35], demonstrated that up to $54.4 \%$ of total portal glucose appearance takes place after $120 \mathrm{~min}$ of consumption of diets, from 120 - $480 \mathrm{~min}$, thus providing additional support to the biological relevance of extended times beyond $2 \mathrm{~h}$ of small intestinal digestion for starch hydrolysis.

Similarly to starch digestion, intestinal mucosal enzymes play a significant role in protein digestion in vivo. Thus, the impact of intestinal mucosal enzyme 
extract, small intestinal $\mathrm{pH}$, and pepsin and pancreatin concentration on isolated whey protein digestion was also evaluated in this study. Under original conditions of digestion (i.e. high pepsin and pancreatin and small intestinal $\mathrm{pH} 7.2 \pm$ 0.2 ), around $5 \%$ and $57 \%$ free amino groups were measured after $2 \mathrm{~h}$ of gastric phase and $4 \mathrm{~h}$ of small intestinal digestion, respectively, both in the absence and presence of intestinal mucosal extract at the concentration optimized for starch hydrolysis $(70 \mathrm{mIU})$. Not unexpectedly, lowering pepsin and pancreatin inclusion by a factor of 11 and 9, respectively, resulted in about $1.5 \%$ free amino group release in the gastric phase and about $20 \%$ lower free amino groups released during the small intestinal phase lacking mucosal enzymes, compared to original conditions of digestion. However, addition of mucosal enzyme extract restored digestibility to comparable levels (around 55\%) to those observed under original conditions of digestion, independently of the small intestinal $\mathrm{pH}(7.2 \pm$ 0.2 or $6.3 \pm 0.2$ ). To our knowledge, neither an optimum $\mathrm{pH}$ nor a dose inclusion of intestinal mucosal enzymes that physiologically simulate food digestion in vivo have been reported in the literature, the complexity of the brush border membrane enzyme composition and distribution along the gastrointestinal tract, together with the variable $\mathrm{pH}$ from proximal to distal small intestine [32] [36] likely being major challenging factors. Thus, it was rational to determine the dose inclusion of intestinal mucosal extracts to reflect literature-reported digestive properties of reference starch substrates and to provide evidence that conditions optimized for starch digestion (70 m IU RIP, $211 \mathrm{U}$ pepsin and $7 \mathrm{U}$ trypsin activity from pancreatin, per digestion reaction, and intestinal $\mathrm{pH} 6.3 \pm 0.2$ ), were also adequate for protein and lipid digestion. For comparison, when converting the enzymatic activities into Units/g food, inclusion levels of pepsin and trypsin activity from pancreatin in our system were estimated to be, respectively, 2 and 6 times lower than the ones recommended in the standardized static in vitro digestion model which does not include intestinal mucosal enzymes [17].

Reference [20] observed 55\% degree of hydrolysis of whey isolated protein after $1 \mathrm{~h}$ gastric plus $1 \mathrm{~h}$ duodenal digestion under conditions similar to the recently proposed harmonized model [17]. Interestingly, these authors also demonstrated about $16 \%$ further extension of whey protein isolate hydrolysis (71\%), when the $1 \mathrm{~h}$ gastrointestinal digests were incubated with BBMs vesicles from pigs for additional $6 \mathrm{~h}$. This value of milk protein digestibility in the presence of $\mathrm{BBM}$ vesicles is higher than that observed in our study $(50 \%-55 \%$ free amino groups) and could be explained by several factors. First, in our study, free amino group analysis of digested samples was performed on supernatants from TCA precipitation and a number of free amino groups from larger molecular weight peptides are removed in the precipitated fraction, this likely resulting in underestimation of free amino groups released from digestion and, hence, digestibility. Second, for each time point of digestion, we report free amino group values in digested samples after deducting those from blanks (digestive solutions and enzymes) that are incubated at $37^{\circ} \mathrm{C}$, thus correcting for proteolysis of the digestive 
enzymes. Progressive auto-digestion of enzymes in intestinal digestive mixtures lacking any substrate and incubated at $37^{\circ} \mathrm{C}$ for $6 \mathrm{~h}$ was recently evidenced [37]. While it is relevant to take into account the contribution of enzyme auto-digestion, it is also reasonable to assume that higher endogenous proteolysis will occur in the absence than in the presence of protein substrate in the digestive solutions, this resulting in overestimation of auto-proteolysis in blanks and, consequently, underestimation of protein hydrolysis.

Further evidence of proteolysis extension in this study was provided by SDS-PAGE protein profiles which demonstrated a more rapid hydrolysis of $\alpha$-lactoglobulin component of whey protein isolate versus $\beta$-lactoglobulin in the gastric phase and extensive hydrolysis of both components at the end of $4 \mathrm{~h}$ small intestinal digestion. Similar hydrolysis profiles have been reported by others after in vitro digestion of milk proteins [38] [39]. Furthermore, tracking the in vivo release of bioactive peptides in the gut of pigs eating milk formulas [40] has shown similar protein profiles of hydrolysis of whey protein components: rapid hydrolysis of $\alpha$-lactoglobulin and higher resistance of $\beta$-lactoglobulin at the duodenum site, both being fully hydrolyzed at the jejunal site.

Reference [22] reported that only $5 \%$ of static in vitro digestion models published between 1967 and 2015 included a lipase during the gastric phase. In our study, non-specific lipase from Candida rugosa was utilized as a surrogate of gastric lipase. Human gastric lipase is not commercially available and, while different biochemical properties are recognized [22] [41], a variety of fungal, microbial and mammalian enzymes have been used on a number of models that do mimic gastric lipolysis. A crude rabbit gastric extract was shown to result in similar rates of lipolysis of meal triacylglycerols compared to human digestive lipases recorded under the same in vitro conditions [42]. In addition, an assessment of the digestive properties of Rhizopus oryzae, gastric rabbit and recombinant human (rHGL) gastric lipases in vitro [43] showed differences in extent of digestion, fatty acids affinity and morphology changes of oil globules during digestion of infant formula among the three lipases and, based on expectations from previous in vivo data, rHGL was shown to be the best surrogate for in vitro models. Fungal lipase was included in the gastric phase of an in vitro digestion looking at the immunogenic proteins and peptides released from cooked pasta [3]. More recently, a study evaluating the impact of different experimental factors, reported addition of Aspergillus niger lipase to the gastric juice for in vitro digestion of fish lipid to obtain triglyceride hydrolysis levels close to that occuring in vivo [44].

It has been reported that lipase activity in the stomach may account for up to $10 \%$ and $25 \%$ of TAGs in solid and liquid meals, respectively [45] [46], with $95 \%$ overall efficiency of fat absorption in humans [47]. In our study, lipolysis of olive oil resulted in about $6 \%$ FFA (w/w) release after $2 \mathrm{~h}$ of gastric digestion and reached about $70 \% \mathrm{FFA}(\mathrm{w} / \mathrm{w})$ at the end of $4 \mathrm{~h}$ small intestinal digestion. These values, together with the very low recovery of TAG (less than $5 \% \mathrm{w} / \mathrm{w}$ ) at the end of digestion, support high digestibility of the lipid oil under the final conditions 
of the in vitro digestion model.

The suitability of the model to provide, in a single reaction, digestibility data on the three macronutrients present in a whole food system (Ensure nutrition powder) was also demonstrated in this study. According to the nutrition facts label, Ensure's carbohydrate fraction includes corn syrup, maltodextrin and sucrose. Digestion of both corn syrup and maltodextrin is expected to generate equivalent glucose content. However only about half of sucrose's weight will be converted into glucose as it is a disaccharide composed of glucose and fructose. Based on the $60 \%$ carbohydrate content (of which 23\% sugars), after deducting the theoretical fructose content of sucrose ingredient, maximum glucose (i.e. $100 \%$ digestion) that could be expected to be released from digestion would be about $70 \%$ of the total carbohydrate fraction. Our results showed increased glucose release with time, maximized at around $64 \%$ glucose after $3 \mathrm{~h}$ of intestinal digestion, i.e. about $90 \%$ digestion, this demonstrating nearly complete in vitro digestibility of carbohydrate fraction. Also, in vitro digestion of corn oil, lipid component of Ensure, resulted in 11\% FFA (w/w) released during the gastric phase and 66\% FFAs (w/w) after $4 \mathrm{~h}$ small intestinal digestion, the later value indicating high digestibility. Corn oil is a well-absorbed fat for which in vivo digestibility coefficient in human subjects has been reported to range between 95.4\% and 97.4\% [48] [49]. Finally, in vitro digestion of the mixed protein fraction in Ensure (including sodium and calcium caseinates and soy protein isolate), while at an apparently slower rate, showed an extent at the end of the small intestinal digestion comparable to that obtained with reference single ingredient whey protein isolate. In vivo data has shown slower casein and soy protein digestion than whey protein, mostly evidenced by more rapid increase in plasma amino acid levels after ingesting whey protein [50] [51] [52]. However, efficiency of casein and soy breakdown in vivo is comparable to that of whey protein as indicated by high true digestibility levels [53] [54].

Despite the added complexity in composition of final digestive solution in this model due to the integration of small intestinal enzyme extract, our results were consistent and reproducible, as shown by lower than $8 \% \mathrm{CV}$ at different times of small intestinal digestion for both corn starch and whey protein isolate, obtained from 3 independent experiment including 3 different batches of small intestinal enzyme extract tested, for each substrate, in triplicate.

Future perspectives of the model include its application to the understanding of how food composition, food matrix, particle size, processing and other conditions, impact the digestibility of either one or all three macronutrients in a food, this knowledge being relevant for the development of innovative food ingredients and foods that target delivery of nutrients to specific points of the gastrointestinal tract as well as foods with optimal nutritional properties.

\section{Conclusion}

In conclusion, the present study reports the development of an in vitro digestion 
model that includes intestinal mucosal enzymes as an integral parameter in the small intestinal phase of digestion and demonstrates its suitability to evaluate the digestive profiles of all three macronutrients. The good reproducibility, together with the digestion profiles observed for reference materials being consistent with in vitro and vivo data, supports the validity of this method as an advanced and robust in vitro tool for screening digestion of all three macronutrients, carbohydrates, proteins and lipids, whether separately or in a food, in a single digestion reaction.

\section{Acknowledgements}

We thank Alvin Berger for support and advice in the initial design of the in vitro method and Kerry Ros for technical support on GC methodologies, both of whom were formerly employed by Cargill.

\section{Author Contributions}

Vicenta Garcia-Campayo (corresponding author; data acquisition, analysis and interpretation; writing of the manuscript), Sonia Han (data acquisition and analysis), Ronny Vercauteren (expertise and experimental protocol for intestinal mucosal enzymes), Anne Franck (conception of the work, discussion of data and review of the manuscript). All authors have read and approved the manuscript.

\section{Conflict of Interest Declaration}

Authors are employed by Cargill.

\section{References}

[1] Dupont, D., Le Feunteun, S., Marze, S. and Souchon, I. (2018) Structuring Food to Control Its Disintegration in the Gastrointestinal Tract and Optimize Nutrient Bioavailability. Innovative Food Science and Emerging Technologies, 46, 83-90. https://doi.org/10.1016/j.ifset.2017.10.005

[2] Singh, J., Dartois, A. and Kaur, L. (2010) Starch Digestibility in Food Matrix: A Review. Trends in Food Science and Technology, 21, 168-180.

https://doi.org/10.1016/j.tifs.2009.12.001

[3] Mamone, G., Nitride, Ch., Picariello, G., Addeo, F., Ferrancti, P. and Mackie, A. (2015) Tracking the Fate of Pasta (T. durum Semolina) Immunogenic Proteins by in Vitro Simulated Digestion. Journal of Agricultural and Food Chemistry, 63, 2660-2667. https://doi.org/10.1021/jf505461x

[4] Guerra, A., Etienne-Mesmin, L., Livrelli, V., Denis, S., Blanquet-Diot, S. and Alric, M. (2012) Relevance and Challenges in Modeling Human Gastric and Small Intestinal Digestion. Trends in Biotechnology, 30, 591-600. https://doi.org/10.1016/j.tibtech.2012.08.001

[5] Minekus, M., Smeets-Peeters, M., Bernalier, A., Marol-Bonnin, S., Havenaar, R., Marteau, P., Alric, M., Fonty, G. and Huis in't Veld, J.H. (1999) A Computer-Controlled System to Simulate Conditions of the Large Intestine with Peristaltic Mixing, Water Absorption and Absorption of Fermentation Products. Applied Microbiology and Biotechnology, 53, 108-114. https://doi.org/10.1007/s002530051622 
[6] Wickham, M., Faulks, R. and Mills, C. (2009) In Vitro Digestion Methods for Assessing the Effect of Food Structure on Allergen Breakdown. Molecular Nutrition and Food Research, 53, 952-958. https://doi.org/10.1002/mnfr.200800193

[7] Ménard, O., Cattenoz, T., Guillemin, H., Souchon, I., Deglaire, A., Dupont, D. and Picque, D. (2014) Validation of a New in Vitro Dynamic System to Simulate Infant Digestion. Food Chemistry, 145, 1039-1045. https://doi.org/10.1016/j.foodchem.2013.09.036

[8] Dupont, D., Alric, M., Blanquet-Diot, S., Bornhorst, G., Cueva, C., Deglaire, A., Denis, S., Ferrua, M., Havenaar, R., Lelieveld, J., Mackie, A.R., Marzoratin, M., Menard, O., Minekus, M., Miralles, B., Recio, I. and Van den Abbeele, P. (2018) Can Dynamic in Vitro Digestion Systems Mimic the Physiological Reality? Critical Reviews in Food Science and Nutrition, 23, 1-17.

https://doi.org/10.1080/10408398.2017.1421900

[9] Hur, S.J., Lim, B.O., Decker, E.A. and McClements, D.J. (2011) In Vitro Human Digestion Models for Food Applications. Food Chemistry, 125, 1-12. https://doi.org/10.1016/j.foodchem.2010.08.036

[10] Woolnough, J.W., Monro, J.A., Brennan, Ch.S. and Bird, A.R. (2008) Simulating Human Carbohydrate Digestion in Vitro: A Review of Methods and the Need for Standardization. Food Science and Technology, 43, 2245-2256.

[11] Englyst, H.N., Kingman, S.M. and Cummings, J.H. (1992) Classification and Measurement of Nutritionally Important Starch Fractions. European Journal of Clinical Nutrition, 46, S33-S50.

[12] Li, Y., Hu, M. and McClements, D.J. (2011) Factors Affecting Lipase Digestibility of Emulsified Lipids Using an in Vitro Digestion Model: Proposal for a Standardized pH-Stat Method. Food Chemistry, 126, 498-505. https://doi.org/10.1016/j.foodchem.2010.11.027

[13] Helbig, A., Silletti, E., Timmerman, E., Hamer, R.J. and Gruppen, H. (2012) In Vitro Study of Intestinal Lipolysis Using pH-Stat and Gas Chromatography. Food Hydrocolloids, 28, 10-19. https://doi.org/10.1016/j.foodhyd.2011.11.007

[14] Rothenbuhler, E. and Kinsella, E. (1985) The pH-Stat Method for Assessing Protein Digestibility: An Evaluation. Journal of Agricultural and Food Chemistry, 33, 433-438. https://doi.org/10.1021/jf00063a027

[15] Kopf-Bolanz, K.A., Schwander, F., Gijs, M., Vergères, G., Portmann, R. and Egger, L. (2012) Validation of an in Vitro Digestive System for Studying Macronutrient Decomposition in Humans. The Journal of Nutrition, 142, 245-250. https://doi.org/10.3945/jn.111.148635

[16] Hollebeeck, S., Borlon, F., Schenider, Y.-J., Larondelle, Y. and Rogez, H. (2013) Development of a Standardized Human in Vitro Digestion Protocol Based on Macronutrient Digestion Using Response Surface Methodology. Food Chemistry, 138, 1936-1944. https://doi.org/10.1016/j.foodchem.2012.11.041

[17] Minekus, M., Alminger, M., Alvito, P., Balance, S., Bohn, T., Bourlieu, C., Carrère, F., Boutrou, R., Corredig, M., Dupont, D., Bordkorb, A., et al. (2014) A Standardized Static in Vitro Digestion Method Suitable for Food-An International Consensus. Food and Function, 5, 1113-1124. https://doi.org/10.1039/C3FO60702J

[18] Goodman, B.E. (2010) Insights into Digestion and Absorption of Major Nutrients in Humans. Advances in Physiology Education, 34, 44-53. https://doi.org/10.1152/advan.00094.2009

[19] Picariello, G., Ferranti, P., Fierro, O., Mamone, G., Caira, S., Di Luccia, A., Monica, S. and Addeo, F. (2010) Peptides Surviving the Simulated Gastrointestinal Digestion 
of Milk Proteins: Biological and Toxicological Implications. Journal of Chromatography B, 878, 295-308. https://doi.org/10.1016/j.jchromb.2009.11.033

[20] Picariello, G., Miralles, B., Mamone, G., Sánchez-Rivera, L., Recio, I., Addeo, F. and Ferranti, P. (2015) Role of Intestinal Brush Border Peptidases in the Simulated Digestion of Milk Proteins. Molecular Nutrition and Food Research, 59, 948-956. https://doi.org/10.1002/mnfr.201400856

[21] Versantvoort, C.H.M., Oomen, A.G., Van den Kama, E., Rompelberg, C.J.M. and Sips, A.J.A.M. (2005) Applicability of an in Vitro Digestion Model in Assessing the Bioaccessibility of Mycotoxins from Food. Food and Chemical Toxicology, 43, 31-40. https://doi.org/10.1016/j.fct.2004.08.007

[22] Sams, L., Paume, J., Giallo, J. and Carrière, F. (2016) Relevant pH and Lipase for in Vitro Models of Gastric Digestion. Food and Function, 7, 30-45. https://doi.org/10.1039/C5FO00930H

[23] Ikarashi, N., Takeda, R., Ito, K., Ochiai, W. and Sugiyama, K. (2011) The Inhibition of Lipase and Glucosidase Activities by Acacia Polyphenol. Evidence-Based Complementary and Alternative Medicine, 2011, Article ID: 272075.

[24] Lee, B.-H., Rose, D.R., Lin, A.H.-M., Quezada-Calvillo, R., Nichols, B.L. and Hamaker, B.R. (2016) Contribution of the Individual Small Intestinal $\alpha$-Glucosidases to Digestion of Unusual $\alpha$-Linked Glycemic Disaccharides. Journal of Agricultural and Food Chemistry, 64, 6487-6494. https://doi.org/10.1021/acs.jafc.6b01816

[25] Kim, Y.S. and Brophy, E.J. (1976) Rat Intestinal Brush Border Membrane Peptidases. The Journal of Biological Chemistry, 25, 3190-3205.

[26] Yvon, M., Chabanet, C. and Pélissier, J.P. (1989) Solubility of Peptides in Trichloroacetic Acid (TCA) Solutions. International Journal of Peptide and Protein Research, 34, 166-176. https://doi.org/10.1111/j.1399-3011.1989.tb00227.x

[27] Nielsen, P.M., Petersen, D. and Dambmann, C. (2001) Improved Method for Determining Food Protein Degree of Hydrolysis. Journal of Food Science: Food Chemistry and Toxicology, 66, 642-646. https://doi.org/10.1111/j.1365-2621.2001.tb04614.x

[28] Navarrette del Toro, M.A. and García-Carreño, F.L. (2005) Evaluation of the Progress of Protein Hydrolysis. In: Wrolstad, R.E., et al., Eds., Handbook of Food Analytical Chemistry, Wiley Interscience, 2000-2005, Hoboken, 141-154.

[29] Dahlquist, A. (1964) Method for Assay of Intestinal Disaccharidases. Analytical Biochemistry, 7, 18-25. https://doi.org/10.1016/0003-2697(64)90115-0

[30] Larner, J. and Gillespie, R.E. (1956) Hydrolysis of Nigeriose by Intestinal Extracts. Journal of the American Chemical Society, 78, 882. https://doi.org/10.1021/ja01585a054

[31] Ao, Z., Quezada-Calvillo, R., Sim, L., Nicholas, B.L., Rose, D.R., Sterchi, E.E. and Hamaker, B.R. (2007) Evidence of Native Starch Degradation with Human Small Intestinal Maltase-Glucoamylase (Recombinant). FEBS Letters, 581, 2381-2388. https://doi.org/10.1016/j.febslet.2007.04.035

[32] Picariello, G., Ferranti, P. and Addeo, F. (2016) Use of Brush Border Membrane Vesicles to Simulate the Human Intestinal Digestion. Food Research International, 88, 327-335. https://doi.org/10.1016/j.foodres.2015.11.002

[33] Nieva-Echavarría, B., Goicoechea, E., Manzanos, M.J. and Guillén, M.D. (2016) A Study by $1 \mathrm{H}$ NMR on the Influence of Some Factors Affecting Lipid in Vitro Digestion. Food Chemistry, 211, 17-26. https://doi.org/10.1016/j.foodchem.2016.05.021

[34] Zhang, G., Ao, Z. and Hamaker, B.R. (2006) Slow Digestion Property of Native Ce- 
real Starches. Biomacromolecules, 7, 3252-3258. https://doi.org/10.1021/bm060342i

[35] Van Kempen, T., Regmi, P.R., Matte, J.J. and Zijlstra, R.T. (2010) In Vitro Starch Digestion Kinetics, Corrected for Estimated Gastric Emptying, Predict Portal Glucose Appearance in Pigs. The Journal of Nutrition, 140, 1227-1233. https://doi.org/10.3945/jn.109.120584

[36] Triadou, N., Bataille, J. and Schmitz, J. (1983) Longitudinal Study of the Human Intestinal Brush Border Membrane Proteins: Distribution of the Main Disaccharidases and Peptidases. Gastroenterology, 85, 1326-1332.

[37] Mat, D.J.L., Le Feunteun, S., Michon, C. and Souchon, I. (2016) In Vitro Digestion of Foods Using pH-Stat and the INFOGEST Protocol: Impact of Matrix Structure on Digestion Kinetics of Macronutrients, Proteins and Lipids. Food Research International, 88, 226-233. https://doi.org/10.1016/j.foodres.2015.12.002

[38] Mandalari, G., Mackie, A.M., Rigby, N.M., Wickham, M.S.J. and Mills, E.N.C. (2009) Physiological Phosphatidylcholine Protects Bovine $\beta$-Lactoglobulin from Simulated Gastrointestinal Proteolysis. Molecular Nutrition and Food Research, 53, S131-S139. https://doi.org/10.1002/mnfr.200800321

[39] Egger, L., Mènard, O., Delgado-Andrade, C., Alvito, P., Assuncāo, R., Balance, S., Barberá, R., Brodkorb, A., Portmann, R., et al. (2016) The Harmonized INFOGEST in Vitro Digestion Method: From Knowledge to Action. Food Research International, 88, 217-225. https://doi.org/10.1016/j.foodres.2015.12.006

[40] Barbé, F., Le Founteun, S., Rémond, D., Ménard, O., Jardin, J., Henry, G., Laroche, B. and Dupont, D. (2014) Tracking the In Vivo Release of Bioactive Peptides in the Gut during Digestion: Mass Spectrometry Peptidomic Characterization of Effluents Collected in the Gut of Dairy Matrix Fed Mini-Pigs. Food Research International, 63, 147-156. https://doi.org/10.1016/j.foodres.2014.02.015

[41] Borlieu, C., Rousseau, F., Briard-Bion, V., Madec, M.N. and Bouhallab, S. (2012) Hydrolysis of Native Milk Fat Globules by Microbial Lipases: Mechanisms and Modulation of Interfacial Quality. Food Research International, 49, 533-544. https://doi.org/10.1016/j.foodres.2012.07.036

[42] Capolino, P., Guérin, C., Paume, J., Giallo, J., Ballester, J.-M., Cavalier, J.-F. and Carrière, F. (2011) In Vitro Gastrointestinal Lipolysis: Replacement of Human Digestive Lipases by a Combination of Rabbit Gastric and Porcine Pancreatic Extracts. Food Digestion, 2, 43-51. https://doi.org/10.1007/s13228-011-0014-5

[43] Sassene, P.J., Fano, M., Mu, H., Rades, T., Aquistapace, S., Schmitt, B., Cruz-Hernandez, C., Wooster, T.J. and Müllertz, A. (2016) Comparison of Lipases for in Vitro Models of Gastric Digestion: Lipolysis Using Two Infant Formulas as Model Substrates. Food and Function, 7, 3989-3998.

https://doi.org/10.1039/C6FO00158K

[44] Nieva-Echavarría, B., Goicoechea, E. and Guillén, M.D. (2017) Effect of the Presence of Protein on Lipolysis and Lipid Oxidation Occurring during in Vitro Digestion of Highly Unsaturated Oils. Food Chemistry, 235, 21-33.

https://doi.org/10.1016/j.foodchem.2017.05.028

[45] Carriere, F., Barrownam, J.A., Verger, R. and Laugier, R. (1993) Secretion and Contribution to Lipolysis of Gastric and Pancreatic Lipases during a Test Meal in $\mathrm{Hu}$ mans. Gastroenterology, 105, 876-888. https://doi.org/10.1016/0016-5085(93)90908-U

[46] Meynier, A. and Genot, C. (2017) Molecular and Structural Organization of Lipids in Foods: Their Fate during Digestion and Impact in Nutrition. Oilseeds and Fats Crops and Lipids, 24, D202. https://doi.org/10.1051/ocl/2017006 
[47] Jones, P.J.H. and Kubow, S. (2006) Major Constituents and Energy Needs in Modern Nutrition in Health and Disease.

[48] Mitchell, D.C., McMahon, K.E., Shively, C.A., Apgar, J.L. and Kris-Etherton, P.M. (1989) Digestibility of Cocoa Butter and Corn Oil in Human Subjects: A Preliminary Study. American Journal of Clinical Nutrition, 50, 983-986. https://doi.org/10.1093/ajen/50.5.983

[49] Shahkalili, Y., Duruz, E. and Acheson, K. (2000) Digestibility of Cocoa Butter from Chocolate in Humans: A Comparison with Corn-Oil. European Journal of Clinical Nutrition, 54, 120-125. https://doi.org/10.1038/sj.ejcn.1600905

[50] Boirie, Y., Dangin, M., Gachon, P., Vasson, M.-P., Maubois, J.L. and Beaufrère, B. (1997) Slow and Fast Dietary Proteins Differently Modulate Postprandial Protein Accretion. Proceedings of the National Academy of Sciences, 94, 14930-14935. https://www.ncbi.nlm.nih.gov/pmc/articles/PMC25140/ https://doi.org/10.1073/pnas.94.26.14930

[51] Morifuji, M., Ishizaka, M., Baba, S., Fukuda, K., Matsumoto, H., Koga, J., Kanegae, M. and Higuchi, M. (2010) Comparison of Different Sources and Degrees of Hydrolysis of Dietary Protein: Effect on Plasma Amino Acids, Dipeptides, and Insulin Responses in Human Subjects. Journal of Agricultural and Food Chemistry, 58, 8788-8797. https://doi.org/10.1021/jf101912n

[52] Boutrou, R., Gaudichon, C., Dupont, D., Jardin, J., Arinei, G., Marset-Baglieri, A., Benamouzig, R., Tomé, D. and Leonil, J. (2013) Sequential Release of Milk Protein-Derived Bioactive Peptides in the Jejunum in Healthy Humans. American Journal of Clinical Nutrition, 97, 1314-1323. https://doi.org/10.3945/ajcn.112.055202

[53] FAO/WHO (1991) Protein Quality Evaluation: Report of the Joint FAO/WHO Expert Consultation. FAO Food and Nutrition Paper 51, Rome.

[54] Rutherford, S.M., Fanning, A.C., Miller, B.J. and Moughan, P.J. (2014) Protein Digestibility-Corrected Amino Acid Scores and Digestible Indispensable Amino Acid Scores Differentially Describe Protein Quality in Growing Male Rats. The Journal of Nutrition, 145, 372-379. https://doi.org/10.3945/jn.114.195438 